られ胃体部の詳細は判然としない，依って胃体部の粘 膜船壁の変化をみる為们所謂粘膜隺壁像撮影が行われ

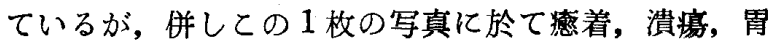
蠕動の異状等の鑑別には尚不充分な場合がある。従つ て連続的に蠕動の変化に伴う粘膜船壁の変化を撮影す る為に余は $24 \mathrm{~cm} \times 24 \mathrm{~cm}$ 大のフィルムを使用出来る 特殊の取枠増感紙を使用し，そ机手動式に連続回転 させ 1 枚のフィルムに $12 \mathrm{~cm} \times 12 \mathrm{~cm}$ 大の影像を 4 回 連続撮影する方式の装置を考案試作したので，その機

\section{VIII. 撮影}

\section{〔1] X線像の仮影研究}

中華民国国防学院物理医学系 主任教授 遣 静

（第 7 回総会特別講演）

\section{[2]写真黑化度と管電流に就て}

レントゲン技術專修学校 滝内政治郎

管電圧を一定にし管電流を種々変化した場合たとえ 同一ミリアンペアセコンドに於ても写真黒化度の変化 することを実験的に追求したもので理論的には同一の 等であるが実際には可成の相異を見出した。よって其 の理由を 1. 管電圧の測定方法の適否. 1. 管電圧, 電流波形の相異等に起因するものと考えその関聯につ き検討を加光た。

（第3 回総会発表）

\section{〔3〕放射中心線の偏位に依り写真浿度に及ぼす影} 響について（中間報告）

伊達日赤 鉿木貞行 (第3 回総会発表)

\section{〔4] $\mathrm{X}$ 線放射角度の変化に依るフィルム漕度及び 対照度の変化について} 伊豆聥信病院 坂内秀郎

須藤祯人・清水克豊

最近臨㦿 X線写真で目的物を的確に把握するため X 線主軸とフィルムとのなす角が写真像形成の幾何学的 関係に応して従来の最も普遍的な $90^{\circ}$ 以外の適当な角 度放射が要求される場合る非常に増加するに至った。 我々はこの角度, 放射に於ける角度の変化に依る濃度 対照度其の他の変化を $\mathrm{X}$ 線の発散娍弱に関する基本的 な法則に依り考究し尚其の変化勾配をも求めて変化状 態の角度特性曲線を理論的に得た。文均一物質を用い
構と使用成樍に就いて述べた。

（第10回総会発表）（第10巻第 3.4 号掲載）

[78〕自作せる十二指腸連続攝影装置に就て

山口医大 秋田宗 寿

胃幽門部，十二指腸起始部の連続撮影装置として連 続撮影に簡便なる透視板を考案自作したので，その使 用結果について報告している。

（第10回総会発表）（第10巻第 3.4 号掲載）

\section{の 部}

て $2 \cdot 3$ の実測值に依り黑化度対照度の散乱線に及ぼさ れる影響をも考虑に入れ実際理論両值の比較検討によ り理論式の補正を求めて実際上の適応を与えんとする ものである.

（第 7 回総会発表）（第 7 巻第 $2 \cdot 3$ 号掲載）

\section{〔5〕軽度の斜位に撮影された胸部写真の考察} 大阪大学医学部 二·宮

片山㴖幸

矢状方向の写真が相当多く斜に写っているのを見る そは胸部写真の読影上ぞれ位の角度に写されているか を知るために，銷骨の骨端と胸椎の側壁と左右の差を 比較するととにした。

(第 8 回総会発表)

\section{［6]管球移動と呼吸深浅に伴う胸腔内指標の移動} 国立青森療養所 村木丈二 従来胸部撮影の場合管球焦点の高さというものが厳 密にされてきた。管球の高さに依って陰影の位置も違 ってくるからである。乙れは理論に於ても又私の行っ た実験に於ても，従来考光られていた程重視すべき問 題ではない事が判り，むしろ問題は管球焦点の高さ以 外にあることを報告した。

(第 6 回総会発表）

\section{〔7〕遮光簡の影像に及ぼす影響}

徳島帝国瀻維医局 大 隅 豊 X. 線直接撮影殊に胸部摄影にあたり被写体に依る二次 線の影響を実験的に検討する為 (A) 㵂光筒なしの場 合.（B）装置に既設の遮光筒， (C) 口径 $10 \mathrm{~cm}$ 長 さ $50 \mathrm{~cm}$ の私作の遮光筒。 (D) 口径 $10 \mathrm{~cm}$ 長さ 100 $\mathrm{cm}$ の私作の㵂光筒によって $200 \mathrm{~cm}$ の距離で実験を 行った結果, 胸部に於ては明らかに A B C D 順序 
による鮮鋭度の差を認めたが，被写体のない場合には 殆んど影響がなかった，其処で $7 \mathrm{~cm}$ の水槽について 実験した処，同様に A BCD の順となった。以上の 結果より放射野の大小が被写体からの二炊線の発生に 影響するものであるから出来得る限り小放射野の遮光 筒を使用しなければならぬ事を述べた。

\section{（第 4 回総会発表）（第 4 巻第 1.2 号掲載）}

\section{〔8〕㠊光物奐に依る写真に及ぼす影響}

泰野赤十字 宮原 勇

写真撮影に有効なX線は $1 \%$ にしかすぎず，その 1 $\%$ X 線も亦吸収散乱等により減弱される．其処で無 駄なく利用する為にカセッテ等に使用されて居る物 質, アルミニューム, 銅, ボール紙, フィルムの保護 紙, 布, ガラス, 木板，セルロイド等を撮影しその吸 収の状態を検討した結果を報告した。

(第 7 回総会発表)

\section{[9]遮光装置使用時に於ける鮮鋭度の検討} 神戸川崎病院 岡㮇房 原 治已

レ線写真撮影に当り写真像の鮮鋭度並に対照度の優 れて居る事は，最も重要である。管球の焦点，距離に よる幾何学的拡大, 増感紙等々の因子は鮮鋭度に関係 深く又相当二次線の影響の大なる部位に於いて遮光装 置の使用が対照度を良好ならしめることは常識とされ ているが鮮鋭度に関しては尚多少の疑義を残している この点に就いて遮光装置の有無が鮮鋭度に如何に変化 を与えるか究明せんとし比較検討を試みたので，その 奏験結果を報告した。

\section{（第 9 回総会発表）}

\section{〔10] $\mathbf{X}$ 線像拡大の実験的測定結果に就て}

名古屋大学医学部 広 住 治 夫

私共が常に撮影しているX線写真は其の像が実物よ り㹡大されて写る事は周知の通りであるが，その桩大 率を増感紙を用いた場合と，用いない場合について実 験的に測定した結果を報告した。

（第 2 回総会発表）（第 2 巻第 3.4 号掲載）

\section{〔11〕 $\mathbf{X}$ 線胸部写真像の精密度について}

国立療養所静澄園 平出富勇

$\mathrm{X}$ 線胸部写真に現れない小さい病巣がどの税度の限 界にあるものか一定の表示がない，其処で演者は撮影 方法によりその限界に異同があるのではないかとの考 えのもとに, 胸部の模型により背腹, 腹背等の撮影を
行い検郡した結果，背腹位 1 枚の写真では確実な診断 が出来ず又病巣の位置により $2 \mathrm{~mm}$ 大の病巣を見落さ ない為にも腹背位撮影が必要である事を報告した。

(第 7 回総会発表)

\section{〔12〕乱焦点性の影像に及ぼす影濯に就いて}

$$
\begin{array}{ccc}
\text { 大日本レントゲン } & \text { 丹羽 } & \text { 勇 } \\
\text { 大阪大学医学部 } & \text { 内田 } & \text { 勝 } \\
& \text { 中 } & \text { 仡 }
\end{array}
$$

$\mathrm{X}$ 線管球焦点の乱視現象は周知の事であるが，茲に はその影像に及ぼす影響に就いて報告する。

フィルム上の小球影像を観察し種々なる角度より見 た幾何学的実效焦点の大いさとの間の関係を見出し方 向による影像の変形を知り, 被写体の正確なる形状の 判定をなさんとするものである。

（第 8 回総会発表）

\section{〔13〕 像影の鲜鋭度に就いての実験（第 1 報）}

（特に管球焦点よりも小なる物体の影像につ いて)

市立岡谷病院 小松 好 郎

後 藤 邦 男

$\mathrm{X}$ 線写真の影像の鮮鋭度は，(1)幾何学的无子．(2)運 動による因子．(3)増感紙の粒子による因子（4)増感紙 とフィルムとの関係. (5)散乱線による因子等の諸因子 により関係される事は明らかにされている処であるが 余は管球よりも，小さな物体の影像と幾何学的因子と の関係について実験をなしそれにより帰納された結果 を報告。

（第 8 回総会発表）（第 8 巻第 4 号掲載）

\section{〔14] X線影像の鮮鋭度についての実験（第 2 報）}

市立岡谷病院 後 藤 邦 男

$\mathrm{X}$ 線影像の鮮鋭度は幾何学的因子, 運動に依る因子, フィルム増感紙による因子散乱線による因子等と密接 なる因果的関係にある．余はその中特に管球焦点より 小なる被写体の影像の鮮鋭度に就いて実験的に検討し つつあり，既に第 1 報として結果を報告したが，今回 は新旧各 2 本の管球 $(10 \mathrm{KW}, 6 \mathrm{KW}, 2 \mathrm{KW})$ と当院長 小松博士との共同考察になる特殊遮光円筒とを用いて 身体各部を比較撮影しその鮮鋭度を複式顕微鏡の倍率 による数值を以て表わす事により，管球焦点の大きさ 及び歪形が鮮鋭度に如何なる影響を及ぼすかに就いて 数量的に籍察しつつあるが現在迄にまとまつた所を第 2 報として報告した。

（第10回総会発表）（第10巻第 2 号掲載） 